\section{Lifestyles and living standard disparities in the pandemicity of COVID-19 in the Global North versus the Global South Countries}

\section{Takele Taye Desta}

Department of Biology, College of Natural and Computational Science, Kotebe Metropolitan University, Addis Ababa, Ethiopia

\begin{abstract}
The coronavirus disease-19 (COVID19) pandemic is imposing an extraordinary threat to global health. Consequently, fear has been raised in that the COVID-19 pandemic could disproportionately affect lowincome countries. Low-income countries are mainly concentrated in the Global South of the tropics with a high diversity of pathogens, and a considerable proportion of people living under chronic poverty. All these risks might have made Southern people develop a sort of herd immunity and resilience against a broad range of infections. The analysis of the COVID-19 Worldometers data by using country-, territory-, or conveyance-wise summarized in Global North (64 countries) and Global South (147 countries) suggested the high incidence of COVID-19 infection in the North world countries. However, this should be treated with caution given the low testing and contact tracing, and presumably reporting capacity, by the South World countries. Nevertheless, Southern people are living under minimal healthcare, consequently, their relative wellness amidst the COVID-19 crisis could not be overlooked. The observed differences in infectivity, however, might not be ethnically-biased but most likely they could be due to the differences in the living standard, healthcare systems as well as the lifestyle of Global North versus Global South countries.
\end{abstract}

\section{Lifestyles and living standards disparities in the pandemicity of COVID-19 in the Global North versus the Global South Countries}

There are unfounded thoughts on ethnic-disparity in susceptibility of coronavirus disease-19 (COVID-19). This com- mentary enlightens the current state and the epidemiology of COVID-19 in the Global North and Global South.

A great concern had been raised about the catastrophic impact of COVID-19 in low-income countries. ${ }^{1}$ Nevertheless, at least, given the current state of the pandem ic, COVID-19 has not been as disastrous in the Global South as it had been anticipated. This has enabled low-income countries to take some advantage in terms of time to learn from Europe and the US about con tainment strategies of the pandemic. Furthermore, it has been repeatedly pointed out that the widespread poverty coupled with communal lifestyle as a powerful obstacle to abide by even very basic preventive guidelines in Southern countries. Another aspect which has been underlined recently as a reason to increased COVID-19-related threat to the South is widespread illiteracy and religious attitudes, for which Southern populations might be uncompliant with protection rules such as wearing masks and social distanc ing. Finally, urban communities of low income countries are considered to live in conditions of high population density, in unhygienic conditions, all factors facilitat ing the spread and pathogenicity related to the COVID-19 pandemic.

Fortunately, up-to-date the incidence of COVID-19 in the majority of low-income countries has remained low, although, this could be partly due to low testing and presumably reporting capacity with subsequent underestimation of the cases. While it is true that the inhabitants of low-income countries struggled to survive and thrive under sub-hygienic conditions and poor healthcare systems, there are some considerations to highlight at this stage. First of all, low-income countries are concentrated in the tropics - a region hosting the largest proportion of global biodiversity ${ }^{2}$ - including pathogens. Because of widespread poverty, at least in some regions of lowincome countries, getting access to food, water, shelter, and the very basic antiseptics is very difficult. Consequently, the likelihood of infection related to continuous exposure is high. The cumulative effect of all these odds, however, might favour the disadvantaged populations in low-income countries through phenomena mainly related to resilience against a wide variety of pathogens: resistance and tolerance to infection. ${ }^{3}$ A year-round high temperature in the tropics might be also counterproductive to the COVID-19 surge. Fortunately, a large proportion of inhabitants in low-income countries are living scattered in rural areas, which reduces the spread of the COVID-19.

To verify the actual consequences of the above-cited assumptions about ethnic dis-
Correspondence: Takele Taye Desta, Department of Biology, College of Natural and Computational Science, Kotebe Metropolitan University, P.O. Box 31248, Addis Ababa, Ethiopia.

Fax: +251.116 .600922$

E-mail: takele_taye@yahoo.com

Key words: COVID-19; epidemiological disparity; Global North; Global South; health organization; lifestyle.

Acknowledgments: I acknowledge the editors and anonymous reviewers for their productive comments and editorial works both greatly improved the quality of the paper.

Conflict of interest: the author declares no potential conflict of interest.

Received for publication: 14 April 2020. Revision received: 11 May 2020.

Accepted for publication: 28 May 2020.

This work is licensed under a Creative Commons Attribution-NonCommercial 4.0 International License (CC BY-NC 4.0).

${ }^{\circ}$ Copyright: the Author(s), 2020

Licensee PAGEPress, Italy

Geriatric Care 2020; 6:9025

doi:10.4081/gc.2020.9025

parities in immunity response against COVID-19 infection, a straightforward analysis of the COVID-19 pandemic was performed using country-, territory-, or conveyance-wise summarized Worldometers ${ }^{4}$ data (archived and last updated on 7 April 2020, https:/www.worldometers.info/coronavirus/). Besides, the Wikimedia ${ }^{5}$ database classifying the world into Global North (64 countries) and Global South (147 countries) (https://meta.wikimedia.org/wiki/) was used to compare and put information into context. The t-test statistics of $\mathrm{R}^{6}$ showed that there is a statistically significant high incidence of both COVID-19 per million people $(\mathrm{t}=4.9274, \mathrm{P}=6.249 \mathrm{e}-06)$ and the COVID-19 associated deaths per million people $(\mathrm{t}=2.6681, \mathrm{P}=0.009669)$ in the Global North. However, there is no statistically significant difference between Global North and Global South in the ratio of total deaths $(\mathrm{t}=0.91456, \mathrm{P}=0.3619)$; total recovery $(\mathrm{t}=1.5272, \mathrm{P}=0.1298)$, and total number of patients admitted to intensive care to total cases $(\mathrm{t}=1.3988, \mathrm{P}=0.1634)$. The absence of statistically significant differences might be due to a poor healthcare system and low technical capacity of lowincome-countries and should be therefore interpreted with caution. On the other side, the test per million people is significantly 
Table 1. Descriptive statistics of the COVID-19 database archived by worldometers according to Global North (GN) and Global South (GS) classification of Wikimedia. The data on COVID-19 Coronavirus Pandemic was updated on 7 April 2020 10:45 am GMT. Additional variables were generated from the original data and were included in the analysis.

\begin{tabular}{|c|c|c|c|c|c|}
\hline Variables & Group & Mean & Median & I.Q.R & Range \\
\hline Total cases & $\begin{array}{l}\text { GS } \\
\text { GN }\end{array}$ & $\begin{array}{c}1565 \\
17639.8\end{array}$ & $\begin{array}{c}74 \\
1191.0\end{array}$ & $\begin{array}{c}14-445 \\
381.2-7278.8\end{array}$ & $\begin{array}{c}1-81740 \\
1-367650.0\end{array}$ \\
\hline Total deaths & $\begin{array}{l}\text { GS } \\
\text { GN }\end{array}$ & $\begin{array}{c}68.18 \\
1029.3\end{array}$ & $\begin{array}{l}2.00 \\
28.5\end{array}$ & $\begin{array}{c}0-8.50 \\
3.5-183.2\end{array}$ & $\begin{array}{l}0-3872.00 \\
0-16523.0\end{array}$ \\
\hline Total recovered & $\begin{array}{l}\text { GS } \\
\text { GN }\end{array}$ & $\begin{array}{c}780.70 \\
2792.05\end{array}$ & $\begin{array}{c}5.00 \\
129.50\end{array}$ & $\begin{array}{c}1.00-51.50 \\
31.75-523.00\end{array}$ & $\begin{array}{l}0-77167.00 \\
0-43208.00\end{array}$ \\
\hline Active cases & $\begin{array}{l}\text { GS } \\
\text { GN }\end{array}$ & $\begin{array}{l}716.20 \\
13818\end{array}$ & $\begin{array}{l}54.00 \\
1042\end{array}$ & $\begin{array}{c}11.00-365.00 \\
297-5948\end{array}$ & $\begin{array}{c}1.00-31678.00 \\
1-336897\end{array}$ \\
\hline Serious or critical cases & $\begin{array}{l}\text { GS } \\
\text { GN }\end{array}$ & $\begin{array}{c}42.1 \\
646.09\end{array}$ & $\begin{array}{c}0 \\
25.50\end{array}$ & $\begin{array}{c}0-6 \\
4.75-156.00\end{array}$ & $\begin{array}{c}0-3987.0 \\
0-8983.00\end{array}$ \\
\hline Total cases/million people & $\begin{array}{l}\text { GS } \\
\text { GN }\end{array}$ & $\begin{array}{l}107.16 \\
1243.9\end{array}$ & $\begin{array}{l}20.00 \\
446.5 \\
\end{array}$ & $\begin{array}{c}4-91.50 \\
220.8-1410.5\end{array}$ & $\begin{array}{c}0.09-1202.00 \\
0-8739.0\end{array}$ \\
\hline Total deaths/million people & $\begin{array}{l}\text { GS } \\
\text { GN }\end{array}$ & $\begin{array}{l}3.138 \\
46.87\end{array}$ & $\begin{array}{c}0.200 \\
8.00\end{array}$ & $\begin{array}{c}0-1 \\
1.00-31.25\end{array}$ & $\begin{array}{c}0-140.000 \\
0-943.00\end{array}$ \\
\hline Total tests & $\begin{array}{l}\text { GS } \\
\text { GN }\end{array}$ & $\begin{array}{c}9950 \\
129079\end{array}$ & $\begin{array}{c}268 \\
27844\end{array}$ & $\begin{array}{c}0-5046 \\
2495-99963\end{array}$ & $\begin{array}{c}0-220000 \\
0-1933423\end{array}$ \\
\hline Total tests/million people & $\begin{array}{l}\text { GS } \\
\text { GN }\end{array}$ & $\begin{array}{c}1166 \\
10971\end{array}$ & $\begin{array}{c}48 \\
6208\end{array}$ & $\begin{array}{c}0-602 \\
2376-12300\end{array}$ & $\begin{array}{c}0-28023 \\
0-103043\end{array}$ \\
\hline Total deaths/Total cases & $\begin{array}{l}\text { GS } \\
\text { GN }\end{array}$ & $\begin{array}{c}0.03819 \\
0.032330\end{array}$ & $\begin{array}{l}0.01754 \\
0.019367\end{array}$ & $\begin{array}{c}0.00000-0.05091 \\
0.007774-0.040088\end{array}$ & $\begin{array}{c}0.00000-0.25000 \\
0.000000-0.222222\end{array}$ \\
\hline Total recovered/Total cases & $\begin{array}{l}\text { GS } \\
\text { GN }\end{array}$ & $\begin{array}{l}0.13665 \\
0.17950\end{array}$ & $\begin{array}{l}0.07713 \\
0.10202\end{array}$ & $\begin{array}{l}0.00000-0.19777 \\
0.04197-0.25831\end{array}$ & $\begin{array}{l}0.00000-0.94405 \\
0.00000-0.86938\end{array}$ \\
\hline Active cases/Total cases & $\begin{array}{l}\text { GS } \\
\text { GN }\end{array}$ & $\begin{array}{c}0.82516 \\
0.7882 \\
\end{array}$ & $\begin{array}{c}0.87500 \\
0.8569\end{array}$ & $\begin{array}{c}0.73656-0.94391 \\
0.7027-0.9228\end{array}$ & $\begin{array}{c}0.01519-1.00000 \\
0.1152-1.0000\end{array}$ \\
\hline Serious or critical cases/Total cases & $\begin{array}{l}\text { GS } \\
\text { GN }\end{array}$ & $\begin{array}{l}0.01890 \\
0.02466\end{array}$ & $\begin{array}{l}0.00000 \\
0.01892\end{array}$ & $\begin{array}{l}0.00000-0.02329 \\
0.01039-0.03184\end{array}$ & $\begin{array}{l}0.00000-0.25806 \\
0.00000-0.08290\end{array}$ \\
\hline Total deaths/Total cases per million people & $\begin{array}{l}\text { GS } \\
\text { GN }\end{array}$ & $\begin{array}{c}0.03844 \\
0.028690\end{array}$ & $\begin{array}{l}0.01765 \\
0.019071\end{array}$ & $\begin{array}{c}0.00000-0.05181 \\
0.006785-0.037722\end{array}$ & $\begin{array}{c}0.00000-0.22222 \\
0.000000-0.124544\end{array}$ \\
\hline
\end{tabular}

low in the Global South $(\mathrm{t}=4.5432$, $\mathrm{P}=2.44 \mathrm{e}-05)$, which might have underestimated the incidence of the circulating COVID-19 compounded with the low reporting capacity of the Global South. Descriptive statistics of the COVID-19 incidence variables are presented in Table 1.

This preliminary analysis does not demonstrate the ethnical disparity in resilience to COVID-19, but it highlights the large variation in the incidence of the pandemic between Global North and Global South. This might be due to gene-environment interactions among others, although there are no data from similarly treated but ethnically divergent patients. Most likely, it is the health history and lifestyle of the individuals that make them susceptible or resilient to the pandemic, not their ethnic background.

\section{References}

1. Gilbert M, Pullano G, Pinotti F, et al. Preparedness and vulnerability of African countries against importations of COVID-19: a modelling study. Lancet 2020;395:871-77.

2. Cincotta RP, Wieniawski J, Engelman R. Human population in the biodiversity hotspots. Nature 2000;404 990-92.
3. Weis S, Rubio I, Ludwig K, et al. Hormesis and defense of infectious disease. Int J Mol Sci 2017;18:1273.

4. Worldometers. COVID-19 Coronavirus Pandemic. Available from: https://www. worldometers.info/coronavirus/ Accessed: 7 April 2020.

5. Wikimedia. List of countries by regional classification. Available from: https:// meta.wikimedia.org/wiki/ Accessed: 3 April 2020.

6. R Core Team. R: A language and environment for statistical computing. $\mathrm{R}$ Foundation for Statistical Computing 2016, Vienna, Austria. Available from: https://www.R-project.org/ 